\title{
Biochar as an Alternative Soil Amendment for Establishment of Northern Highbush Blueberry
}

\author{
Bryan K. Sales \\ Department of Horticulture, Agricultural and Life Sciences Building 4017, \\ Oregon State University, Corvallis, OR 97331 \\ David R. Bryla \\ U.S. Department of Agriculture, Agricultural Research Service, Horticultural \\ Crops Research Unit, 3420 NW Orchard Avenue, Corvallis, OR 97330
}

Kristin M. Trippe

U.S. Department of Agriculture, Agricultural Research Service, Forage Seed and Cereals Research Unit, 3450 SW Campus Way, Corvallis, OR 97331

Carolyn F. Scagel

U.S. Department of Agriculture, Agricultural Research Service, Horticultural Crops Research Unit, 3420 NW Orchard Avenue, Corvallis, OR 97330

\author{
Bernadine C. Strik \\ Department of Horticulture, Agricultural and Life Sciences Building 4017, \\ Oregon State University, Corvallis, OR 97331
}

Dan M. Sullivan

Department of Crop and Soil Science, Agricultural and Life Sciences Building 3017, Oregon State University, Corvallis, OR 97331

Additional index words. bokashi, ericoid mycorrhizal fungi, plant nutrition, Vaccinium corymbosum, water relations

Abstract. Biochar, as a soil amendment, has been reported to improve plant growth by increasing soil moisture and retaining nutrients. In a previous 12-week greenhouse study with highbush blueberry (Vaccinium hybrid), we found that amending soil with biochar alone or in combination with bokashi (fermented wheat bran) increased plant growth relative to unamended soil. The biochar was produced from mixed conifer species during conversion of wood to energy. In the current study, we aimed to validate the greenhouse findings under field conditions in western Oregon. The specific objectives of this 2-year study were to determine the effect of amending soil with biochar or a combination of biochar and bokashi on growth and early fruit production during establishment of northern highbush blueberry (Vaccinium corymbosum L.). To achieve these objectives, we transplanted 'Duke' blueberry plants into soil that was either unamended or amended with biochar or 4:1 (v/v) mixtures of biochar and bokashi or biochar and douglas fir [Pseudotsuga menziesii (Mirb.) Franco] sawdust. Each amendment was either applied in the planting hole or incorporated into the row. A treatment with douglas fir sawdust incorporated into the row was also included and represented the industry standard for the region. Plants grown in soil amended with biochar (in the planting hole or row) had $40 \%$ to $74 \%$ greater total dry weight at the end of the first growing season and $70 \%$ to $82 \%$ greater fruit yield in the second season than those grown with no amendments or in soil amended with sawdust. However, leaf Mg concentrations were lower with biochar, suggesting it could limit Mg uptake in blueberry. Soil amended with sawdust, on the other hand, was higher in organic matter, microbial activity, and wet stable aggregates than the other soil treatments but resulted in lower leaf $\mathbf{N}$ concentrations during the second year after planting. Unlike in the greenhouse study, biochar had no effect on root colonization by mycorrhizal fungi, and there was no benefit to using biochar with bokashi. Adding $4 \mathrm{~L}$ of biochar to the planting hole was considerably more economical than applying it to the row and cost $\$ 1320 /$ ha less than the industry standard of incorporating sawdust in the row. These findings indicate that biochar is a promising soil amendment for commercial production of highbush blueberry.

The use of biochar as an organic soil amendment has received considerable attention in recent years. Biochar is a highly porous $\mathrm{C}$-rich residue produced by thermal cracking (pyrolysis) of biomass under oxygen-controlled conditions (Lehmann and Joseph, 2009). Like many other sources of organic matter, biochars are known to increase retention of water and nutrients in the soil and to improve porosity and permeability of oxygen and other soil gases (Amoakwah et al., 2017; Major et al., 2010; Sohi et al., 2010). A large fraction of the $C$ in biochar is biologically and chemically stable and, therefore, can persist in soil for many years (Glaser et al., 2001; Spokas et al., 2010). Biochars also have extremely high surface areas and provide excellent sites for hosting beneficial soil microorganisms, such as mycorrhizal fungi (Herath et al., 2013; Lehmann et al., 2011; Luo et al., 2017; Molnár et al., 2016; Nemati et al., 2014).

Often, plant growth and production increases in soils amended with biochar, although responses can vary depending on soil fertility and composition and quality of the biochar (Crane-Droesch et al., 2013; Hussain et al., 2017). Agricultural residues, logging and wood processing residues, municipal solids, livestock/poultry waste, wastewater/sewage sludge, and biosolids are among the most common feedstocks used for biochar (Cao and Harris, 2010; Gonzaga et al., 2017; Lehmann and Joseph, 2009). In general, biochars derived from woody materials are coarse and highly resistant in nature with up to $80 \% \mathrm{C}$ (Duku et al., 2011; Zhang et al., 2008). They are also usually low in ash content and, therefore, tend to have little to no effect on soil $\mathrm{pH}$ (Mukome et al., 2013; Singh et al., 2010).

Blueberry (Vaccinium sp.) is an acidophilic plant adapted to well-drained soils with low $\mathrm{pH}$ (4.2-5.5) and high organic matter $(>4 \%)$ (Retamales and Hancock, 2018). To increase organic matter, growers often incorporate bark or sawdust into the soil before planting blueberry, as well as use them as mulch afterward; however, the cost of these materials is increasing and availability is limited in many regions (Larco et al., 2013a). Recently, we conducted greenhouse experiments to determine whether biochar could be used as an alternative amendment for highbush blueberry (Vaccinium hybrid) (Sales et al., 2020). The biochar in this case was produced from mixed conifers during conversion of wood to energy. Within 12 weeks, the plants grown in soil with the biochar were larger and more heavily colonized by ericoid mycorrhizal fungi than those grown in unamended soil. Additional growth and colonization were achieved in a second experiment conducted under $\mathrm{N}$ limited conditions by adding bokashi (a mix of fermented wheat bran, molasses, and naturally occurring microbes) to the biochar (Sales et al., 2020). With or without bokashi, the biochar increased soil $\mathrm{pH}$ by 0.3 units or less, even when it was incorporated at a rate as high as $20 \%$ by volume.

The objective of the present study was to determine whether biochar could improve growth and early fruit production under field conditions in northern highbush blueberry $(V$. corymbosum L.). Biochar, alone or in combination with bokashi or sawdust, was mixed into the planting hole or the entire row before planting and compared with unamended soil or the conventional practice of incorporating sawdust in the row. Plant response as well as 
amendment costs were considered to identify the best practices for using biochar in blueberry production.

\section{Materials and Methods}

Study site. The study was conducted in a new planting of 'Duke' northern highbush blueberry at the Oregon State University North Willamette Research and Extension Center (lat. $45^{\circ} 17^{\prime} \mathrm{N}$, long. $122^{\circ} 45^{\prime} \mathrm{W}$ ) in Aurora, OR. The soil at the site, a fine-silty, mixed, mesic Pachic Ultic Argixerolls silt loam in the 'Willamette' series (Soil Survey Staff, 2014), had an initial $\mathrm{pH}[1: 1$ (v/v) ratio of soil to water] of 6.2 , a cation exchange capacity of $11.9 \mathrm{cmol} \mathrm{(+)} \mathrm{kg}^{-1}, 3.14 \%$ organic matter, $248 \mathrm{mg} \cdot \mathrm{kg}^{-1} \mathrm{P}$ (Bray-1), and $243 \mathrm{mg} \cdot \mathrm{kg}^{-1} \mathrm{~K}$. The soil was ripped $(0.5-\mathrm{m}$ deep), rototilled, and acidified with 1100 $\mathrm{kg} \cdot \mathrm{ha}^{-1}$ of $99.9 \%$ elemental S (Harmon Systems International, Bakersfield, CA) at 10 weeks before planting (Horneck et al., 2004).

The plants were obtained from a commercial nursery (Fall Creek Farm \& Nursery, Lowell, OR) as 2-year-old container stock (2 L) and transplanted on 15 Sept. 2016. Each plant was actively growing at the time of transplanting and spaced $0.76-\mathrm{m}$ apart in rows of raised planting beds. The beds were $0.4-\mathrm{m}$ high $\times 0.9-\mathrm{m}$ wide and were created using a single-row bed shaper (Kennco Manufacturing, Inc., Ruskin, FL). The rows were centered $3.05-\mathrm{m}$ apart and oriented in a north-south direction.

Soil amendments. Three organic amendments were used in the study, including biochar, bokashi, and douglas fir [Pseudotsuga menziesii (Mirb.) Franco] sawdust. The biochar was produced by gasification at $\approx 750^{\circ} \mathrm{C}$ (Oregon Biochar Solutions, Central Point, OR). This is a commercially available biochar manufactured from mixed conifers during conversion of wood to energy at Biomass One (White City, OR), a 30-MW wood-debrisfired power plant. Biochar was either applied

Received for publication 20 Sept. 2021. Accepted for publication 8 Nov. 2021.

Published online 17 January 2022.

Funds for this research were provided by the Northwest Center for Small Fruits Research, Family Forests of Oregon, and the U.S. Department of Agriculture (CRIS number 2072-21000-048-00D).

We thank Matt Delaney for help with experimental planning, Paul Schreiner for assistance with identifying mycorrhizal structures in the roots, Scott Orr and Suean Ott for technical assistance, and John Miedema for providing the soil amendments.

Mention of trade names or commercial products in this publication is solely for the purpose of providing specific information and does not imply recommendation or endorsement by the U.S. Department of Agriculture.

Current address for B.K.S.: University of North Carolina at Pembroke, 2233 Oxendine Science Building, 1 University Drive, Pembroke, NC 28372.

B.K.S. is a former Ph.D. student.

D.R.B. is the corresponding author. E-mail: david.bryla@usda.gov.

This is an open access article distributed under the CC BY-NC-ND license (https://creativecommons. org/licenses/by-nc-nd/4.0/). to the soil by itself or was mixed $4: 1$, by volume, with either bokashi (rice bran fermented with EM-1 microbial inoculant; TeraGranix, Inc., Alto, TX) or douglas fir sawdust (Decorative Bark, Lyons, OR). A 1-kg sample (airdried) of each amendment was sent to a commercial laboratory (Brookside Laboratories, New Bremen, $\mathrm{OH}$ ) for initial analysis of $\mathrm{pH}$, $\mathrm{C}, \mathrm{N}$, and other nutrients (Table 1).

Experimental design. Treatments were arranged in a randomized complete block design and included 1) biochar in the planting hole, 2) biochar + bokashi in the planting hole, 3) biochar + sawdust in the planting hole, 4) biochar + bokashi in the row, 5) biochar + sawdust in the row, 6) sawdust in the row, and 7) unamended soil. Amendments in the row were incorporated a week before planting and applied by spreading a $0.9-\mathrm{m}$ wide by $0.05-$ or 0.1-m-deep layer of biochar mix (treatments 4 and 5) or sawdust (treatment 6) on the row, respectively, before shaping the beds. Amendments in the planting hole were incorporated immediately before planting and applied by mixing $0.008 \mathrm{~m}^{3}$ of biochar (treatment 1), biochar + bokashi (treatment 2 ), or biochar + sawdust (treatment 3 ) with $0.04 \mathrm{~m}^{3}$ of soil $(0.30$ $\times 0.30 \mathrm{~m}$ area to a depth of $0.45 \mathrm{~m}$ ) at the location in which each plant was transplanted. Thus, amendments containing biochar were mixed with the soil in the area of the planting hole at a rate of $20 \%$ by volume and were incorporated in the row at a rate of $10 \%$ by volume. A lower rate was used in the row to reduce the cost of these treatments. Sawdust was incorporated at a rate of $20 \%$, by volume, which is the industry standard (Hart et al., 2006).

The planting included seven rows of treatment plots, plus a border row on each side, for a total of nine rows. The rows were divided

Table 1. Chemical characteristics of three organic materials used as soil amendments in a new planting of 'Duke' northern highbush blueberry in western Oregon.

\begin{tabular}{lccc}
\hline Characteristic & Biochar & Bokashi & Sawdust \\
\hline $\mathrm{pH}^{\mathrm{z}}$ & 10.0 & 8.7 & 4.5 \\
Moisture (\%) $^{\mathrm{y}}$ & 9.5 & 11.7 & 4.1 \\
$\mathrm{C}: \mathrm{N}$ ratio & 209 & 56 & 196 \\
Total nutrients $^{\mathrm{x}, \mathrm{w}}$ & & & \\
$\mathrm{N}(\%)$ & 0.41 & 1.01 & 0.14 \\
$\mathrm{P}(\%)$ & 0.07 & 0.35 & 0.01 \\
$\mathrm{~K}(\%)$ & 0.81 & 0.85 & 0.04 \\
$\mathrm{Ca}(\%)$ & 0.74 & 1.49 & 0.06 \\
$\mathrm{Mg}(\%)$ & 0.14 & 0.47 & 0.01 \\
$\mathrm{~S}(\%)$ & 0.023 & 0.127 & 0.007 \\
$\mathrm{~B}(\mathrm{ppm})$ & 18.9 & 47.5 & 2.5 \\
$\mathrm{Cu}(\mathrm{ppm})$ & 12.2 & 28.5 & 1.3 \\
$\mathrm{Mn}(\mathrm{ppm})$ & 372 & 642 & 18 \\
$\mathrm{Zn}(\mathrm{ppm})$ & 7.4 & 84.9 & 5.8 \\
\hline $\mathrm{z}$ & &
\end{tabular}

${ }^{\mathrm{z}}$ Analyzed using a 1:2(v/v) ratio of sample to water. ${ }^{\mathrm{y}}$ Samples were weighed, dried at 105 to $110^{\circ} \mathrm{C}$ for $16 \mathrm{~h}$, and reweighed to calculate the moisture content.

${ }^{\mathrm{x}}$ Total $\mathrm{C}$ and $\mathrm{N}$ of the samples were determined by combustion analysis (McGeehan and Naylor, 1988).

wSamples were digested with nitric acid in a microwave and analyzed for $\mathrm{P}, \mathrm{K}, \mathrm{Ca}, \mathrm{Mg}, \mathrm{S}, \mathrm{B}, \mathrm{Cu}, \mathrm{Mn}$, and $\mathrm{Zn}$ by inductively coupled plasma spectrometry (Gavlak et al., 2005; Jones and Case, 1990). into five blocks (based on slope), with treatments randomly assigned to a row in each block. Each treatment plot was 6.4-m long and consisted of eight plants. The middle six plants in each plot were used for measurements. Adjacent plots within a row were separated by a distance of $1.2 \mathrm{~m}$ to avoid crosscontamination between the treatments.

Management of the planting. The plants were irrigated using drip tubing (UniRam; Netafim, Fresno, CA) on each side of the row, near the base of the plants. The tubing had integrated, $3.8 \mathrm{~L} \cdot \mathrm{h}^{-1}$ pressure-compensating emitters every $0.30 \mathrm{~m}$. Irrigation was scheduled based on precipitation and daily estimates of crop evapotranspiration (usbr.gov/pn/agrimet/agrimetmap/araoda.html) and controlled independently in each treatment using electric solenoid valves and an automatic timer (Bryla, 2011). To ensure irrigation was adequate, soil water content was measured weekly in the top $15 \mathrm{~cm}$ of soil profile using a time domain reflectometry (TDR) system (Trase I; SoilMoisture Equip. Corp., Santa Barbara CA); the readings were similar among the treatments and from May through September ranged from $28.9 \%$ to $30.4 \%$ in 2017 (year 1) and $23.5 \%$ to $28.6 \%$ in 2018 (year 2).

The plants were fertilized with liquid ammonium sulfate $(8 \mathrm{~N}-0 \mathrm{P}-0 \mathrm{~K}-9 \mathrm{~S})$ at an annual rate of $56 \mathrm{~kg} \cdot \mathrm{ha}^{-1} \mathrm{~N}$. The fertilizer was applied each year (2017 and 2018) from mid-April to the end of July in 13 equal applications of $4.2 \mathrm{~kg} \cdot \mathrm{ha}^{-1} \mathrm{~N}$ each using water-powered proportional chemical injectors (Model D25F1; Dosatron, Clearwater, FL) (one unit per treatment).

Weeds were controlled using a 1-m-wide sheet of black geotextile landscape fabric (a water flow rate of $6.8 \mathrm{~L} \cdot \mathrm{h}^{-1} \cdot \mathrm{m}^{-2}$ and a density of $0.11 \mathrm{~kg} \cdot \mathrm{m}^{-3}$ as measured by the manufacturer; TenCate Protective Fabrics, OBC Northwest, Inc, Canby, OR) on each side of beds ("zippered" weed mat per Strik et al., 2017). The sheets over-lapped on top of the beds (over the drip tubing) and were tacked in place with $15-\mathrm{cm}$-long steel nails. The fabric was cut and folded back to create a $10 \times 10-\mathrm{cm}$ opening for each plant. Any weeds that grew through the openings were removed by hand. Grass alleyways (1.1-m wide) were planted and maintained by mowing between the beds. No chemicals were needed for pest control.

Plants were pruned in Feb. 2017 and Jan. 2018. All of the flower buds were removed in 2017 to encourage more vegetative growth during the first year after planting (Strik and Buller, 2005). The following year, the plants were pruned to leave between 5 and 30 floral buds per plant depending on vigor, which is recommended to maintain a balance between vegetative growth and fruit production in new plantings of northern highbush blueberry (Strik et al., 2017).

Measurements. Five recently expanded leaves were collected from each plant on 20 July 2017 and 17 July 2018. The leaves were oven-dried for at least $48 \mathrm{~h}$ at $70^{\circ} \mathrm{C}$, ground to pass through a $1-\mathrm{mm}$ sieve, and analyzed for $\mathrm{N}$ using a combustion analyzer (model TruSpec CN; Leco Corp., St. Joseph, MI) 
and for $\mathrm{P}, \mathrm{K}, \mathrm{Ca}, \mathrm{Mg}, \mathrm{S}, \mathrm{B}, \mathrm{Cu}, \mathrm{Fe}, \mathrm{Mn}$, and $\mathrm{Zn}$ using an inductively coupled plasma (ICP) optimal emission spectrophotometer (model Optima 3000DV; Perkin Elmer, Wellesley MA) after microwave digestion with $70 \%(\mathrm{v} / \mathrm{v})$ nitric acid (Gavlak et al., 2005; Jones and Case, 1990).

Ripe fruit were hand-harvested each week from 21 June to 12 July 2018, which covered the entire production window. The berries were counted and weighed to determine yield and mean (weighted) berry weight in each treatment. A sample of 25 berries from each plot were then oven-dried and analyzed for nutrients using the same procedures as described for the leaves. A few weeks after the fruit were harvested, irrigation was withheld for $10 \mathrm{~d}$ (4-15 Aug. 2018) to induce water stress in the plants. There was no precipitation during the period, and daily high air temperature averaged $32.2^{\circ} \mathrm{C}$. Usually, water stress develops within 3 to $7 \mathrm{~d}$ without rain or irrigation during the summer in northern highbush blueberry (Bryla and Strik, 2007). Volumetric soil water content was measured at the beginning and end of the period using the TDR system. Readings were taken using a pair of $15-$ and $30-\mathrm{m}$ TDR probes inserted vertically near the center of each plot. Stem water potential was also measured at midday (12:00-2:00 PM) on one representative plant in each plot using a pressure chamber (model 600; PMS Instrument Co., Albany, OR), following procedures outlined in Bryla and Strik (2007).

One randomly selected plant was harvested destructively from each plot on 7 Oct. 2017 (year 1) and 15 Sept. 2018 (year 2). First, soil samples were collected $\approx 10 \mathrm{~cm}$ from the crown of the plants at depths of 0 to 15 and 15 to $30 \mathrm{~cm}$ (directly between two drip emitters) using a 2-cm-diameter soil probe (Clements Associates Inc., Newton, IA). Each sample was ground to pass through a 1-mm sieve and sent to a commercial laboratory (Brookside Laboratories New Bremen, $\mathrm{OH}$ ) for analysis of soil $\mathrm{pH}[1: 1(\mathrm{v} / \mathrm{v})$ ratio of soil to water], organic matter content, and available nutrients. Organic matter content was determined by loss-on-ignition at $360^{\circ} \mathrm{C}$ (Shulte and Hopkins, 1996); available $\mathrm{N}\left(\mathrm{NH}_{4}-\mathrm{N}\right.$ and $\left.\mathrm{NO}_{3}-\mathrm{N}\right)$ was extracted with $1 \mathrm{M} \mathrm{KCl}$ and determined using automated colorimetric methods (Dahnke and Johnson, 1990); and $\mathrm{P}$ and other nutrients $(\mathrm{K}, \mathrm{Ca}, \mathrm{Mg}$, $\mathrm{SO}_{4}-\mathrm{S}, \mathrm{B}, \mathrm{Cu}, \mathrm{Mn}$, and $\mathrm{Zn}$ ) were extracted using the Bray-1 method (Bray and Kurtz, 1945) and Mehlich 3 method (Mehlich, 1984), respectively, and analyzed by ICP spectrometry. Shoots were then cut at the soil surface and divided into stems and leaves. The root system was carefully removed using a shovel and rinsed under running tap water. A small sample of fresh roots $(2 \mathrm{~g})$ was collected from each plant and examined under a microscope $(115 \times)$ for colonization by mycorrhizal fungi. Each sample was cleared in $10 \% \mathrm{KOH}$ and stained with $0.05 \%$ trypan blue in lactoglycerine (Giovannetti and Mosse, 1980); the percentage of roots colonized by mycorrhizal fungi was quantified using a gridline intersection technique (McGonigle et al., 1990). Leaves, stems, and the remaining roots were oven-dried for at least $48 \mathrm{~h}$ at $60^{\circ} \mathrm{C}$ and weighed. The plants also developed a distinguishable crown during the second growing season, which is normal for northern highbush blueberry; roots were removed from the crown before drying and weighed separately.

Once the plants were removed from the soil, $\approx 1 \mathrm{~kg}$ of soil was collected from the root ball, air-dried on a greenhouse bench, and used for analysis of active $\mathrm{C}$, microbial respiration, and soil aggregation in each treatment. Extra care was taken to not destroy the soil aggregates during the process. To determine active $\mathrm{C}, 2.5 \mathrm{~g}$ of air-dried soil was ground to pass through a $1-\mathrm{mm}$ sieve and combined with $20 \mathrm{~mL}$ of $0.02 \mathrm{M} \mathrm{KMnO}_{4}$ in a $50-\mathrm{mL}$ tube and shaken for $2 \mathrm{~min}$. The soil was then allowed to settle for $8 \mathrm{~min}$, and $0.5 \mathrm{~mL}$ of the supernatant was added to
$49.5 \mathrm{~mL}$ of water and hand-shaken for $10 \mathrm{~s}$. A 2-mL sample of the final solution was measured on a spectrophotometer at $550 \mathrm{~nm}$ (Weil et al., 2003). To measure microbial respiration, $40 \mathrm{~g}$ of air-dried soil was ground to pass through a 2-mm sieve and rewet in a glass beaker to field capacity. The beaker was then placed in a glass canning jar, and a baseline reading was taken to determine the concentration of $\mathrm{CO}_{2}$ in the headspace of the jar using an $\mathrm{CO}_{2}$ analyzer (model G2131; Picarro, Santa Clara, CA). Readings were taken at 0 , 24 , and $96 \mathrm{~h}$, and respiration rate $\left(\mu \mathrm{g} \mathrm{CO}_{2}-\mathrm{C} / \mathrm{g}\right.$ soil/d) was calculated by subtracting readings at 24 and $96 \mathrm{~h}$ from the baseline $(0 \mathrm{~h})$. Soil aggregation was determined using a rainfall simulator (Ogden et al., 1997), as described by Moebius-Clune et al. (2016). Approximately $20 \mathrm{~g}$ of air-dried soil was passed through a 2-mm sieve and collected on a
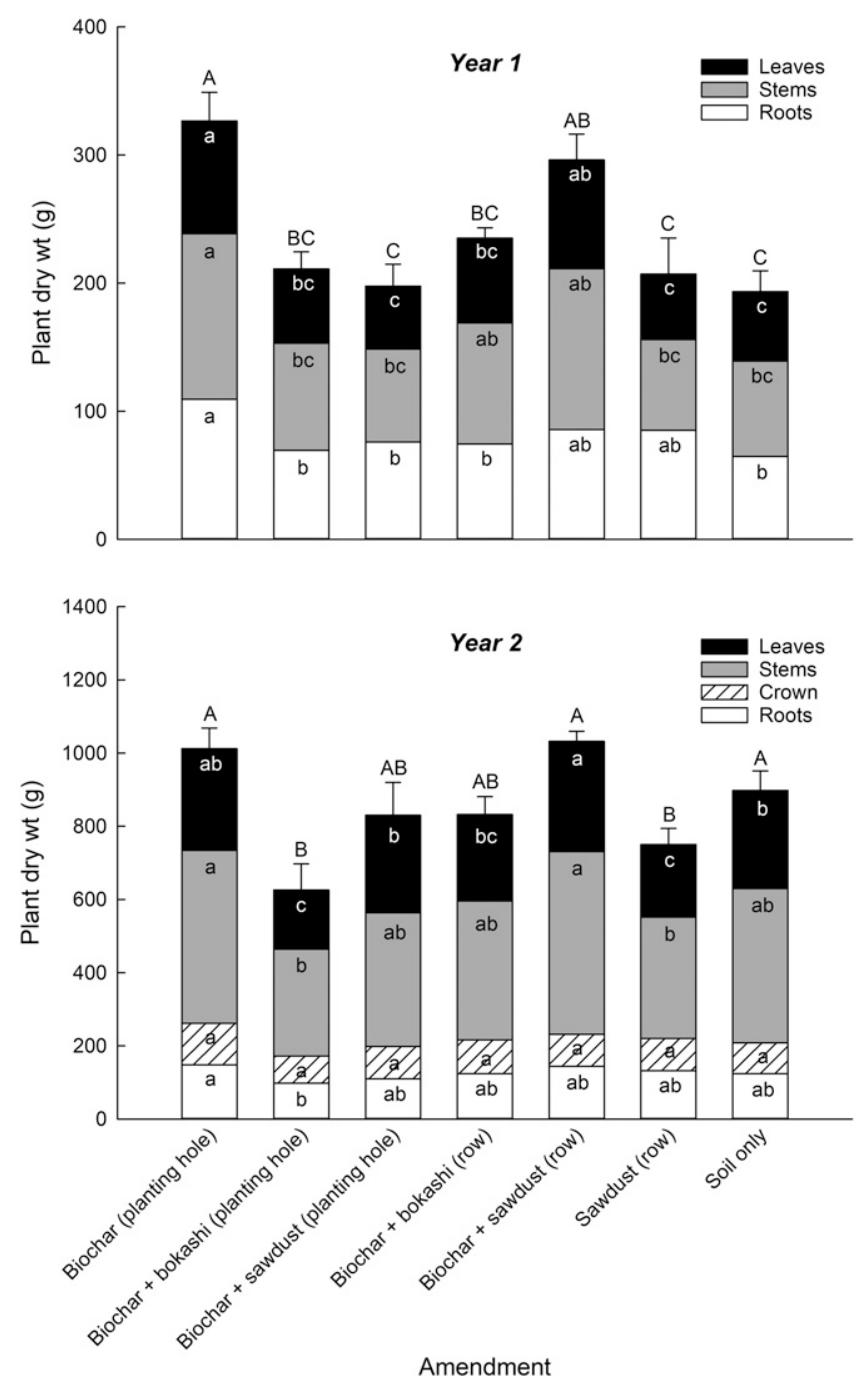

Fig. 1. Effects of soil amendments (biochar, biochar mixed with bokashi or douglas fir sawdust, and sawdust only) on plant dry weight of 'Duke' northern highbush blueberry following the first 2 years after planting in western Oregon. The amendments were incorporated in the planting hole $(20 \%$ by volume) or in the entire row $(10 \%$ by volume for the biochar mixes and $20 \%$ by volume for sawdust) of the planting bed. Incorporation of sawdust in the row is the industry standard. The plants were excavated at the end of the growing season each year and divided into roots, crown (year 2 only), stems (new and old whips and lateral branches), and leaves. Means $(n=5)$ are separated using uppercase letters for total dry weight and lowercase letters for each plant part; those with the same letter are not significantly different, according to Tukey's test $(P \leq 0.05)$. Error bars represent $1 \mathrm{SE}$ of total dry weight of the plants. 
$0.25-\mathrm{mm}$ sieve and weighed. The rainfall simulator was placed $50 \mathrm{~cm}$ above the sieve, and $12.5 \mathrm{~mm}$ of rain was dropped over a 5 -min period, which is equivalent to a heavy thunderstorm. Unstable aggregates passed through the sieve and were collected on filter paper. The filter paper containing the unstable aggregates were dried at $105^{\circ} \mathrm{C}$ for $24 \mathrm{~h}$, weighed, and the weight of the filter paper was subtracted from the total weight to obtain the weight of unstable aggregates. The remaining particles on the sieve were washed to break up the remaining aggregates, and the sieve containing sand-sized fragments was dried at $105^{\circ} \mathrm{C}$ for $24 \mathrm{~h}$ to determine the weight of the sand. Wet stable aggregates are represented as the difference in weight between the sandsized fractions and the weight of the unstable aggregates on the filter paper. The fraction of stable aggregates was calculated by dividing the weight of the stable aggregates by the weight of the total aggregates and multiplying by 100 .

Statistical analysis. The data were analyzed by analysis of variance using the PROC MIXED procedure in SAS software package version 9.3 (SAS Institute, Cary, NC). In most cases, means differed between years and, therefore, data were analyzed separately each year. The independent variables were amendment and block. Data were tested for normality or homogeneity of variance and log-transformed as needed. All data were back transformed to represent the actual means. Means were separated at the 0.05 level using Tukey's honestly significant difference test. Linear regression analysis was done between total dry weight of the plants and yield and berry weight using SigmaPlot v. 14.0 (SPSS, Chicago, IL).

\section{Results}

Plant growth and yield. By the end of the first growing season, plants with biochar in the planting hole produced more total dry weight (sum of roots, stems, and leaves) than those in any other treatment except the one with biochar + sawdust in the row (Fig. 1). Plants with biochar (in the planting hole or row) also produced more fruit than most treatments the following year and, therefore, had a higher yield than several treatments, including those with sawdust and soil only (Fig. 2). Yield increased as a function of the total dry weight of the plants from the previous season (Fig. 2, inset), but was unrelated to berry weight, which was similar among the treatments $(\bar{X}=2.1 \mathrm{~g} /$ berry $)$.

By the end of the second season, plants with biochar in the planting hole or row had a greater dry weight than those grown with biochar + bokashi in the planting hole or sawdust in the row; however, they were no longer different from plants in the other treatments, including those in unamended soil (Fig. 1).

Leaf nutrients. The concentration of several nutrients in the leaves were affected by the soil amendments, including $\mathrm{K}, \mathrm{Mg}, \mathrm{S}$, and $\mathrm{B}$ in year 1 and $\mathrm{N}$ and $\mathrm{Mg}$ in year 2 (Table 2). In most cases, these nutrients were within or above the

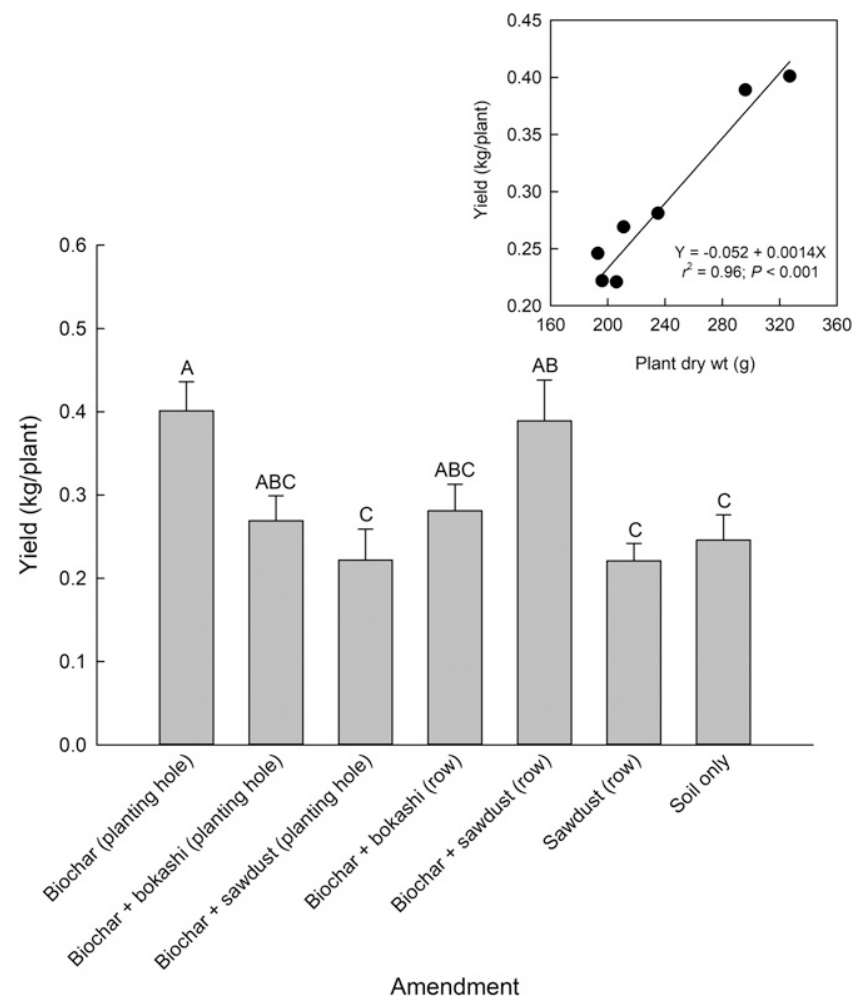

Fig. 2. Effects of soil amendments (biochar, biochar mixed with bokashi or douglas fir sawdust, and sawdust only) on yield of 'Duke' northern highbush blueberry during the second year after planting in western Oregon. The amendments were incorporated in the planting hole ( $20 \%$ by volume) or in the entire row $(10 \%$ by volume for the biochar mixes and $20 \%$ by volume for sawdust) of the planting bed. Incorporation of sawdust in the row is the industry standard. Means $(n=5)$ with the same letter above the bars are not significantly different, according to Tukey's test $(P \leq 0.05)$. Error bars represent 1 SE. Inset: Relationship between yield (year 2) and total plant dry weight from the previous season (year 1). recommended sufficiency range for highbush blueberry in Oregon (Hart et al., 2006). However, $\mathrm{Mg}$ was below the recommended range when plants were grown in soil only in year 1 or with any of the biochar treatments in year 2 . Likewise, $\mathrm{N}$ was below the recommended range when plants were grown with sawdust in the row in year 2, while B was deficient
Table 2. Effects of soil amendments (biochar, biochar mixed with bokashi or douglas fir sawdust, and sawdust only) on the concentration of nutrients in the most recent fully expanded leaves of 'Duke' northern highbush blueberry during the first 2 years after planting in western Oregon.

\begin{tabular}{|c|c|c|c|c|c|c|}
\hline \multirow[b]{3}{*}{ Amendment ${ }^{\mathrm{x}}$} & \multicolumn{6}{|c|}{ Concn of nutrients in recent fully expanded leaves ${ }^{z, y}$} \\
\hline & \multicolumn{4}{|c|}{ Year 1} & \multicolumn{2}{|c|}{ Year 2} \\
\hline & K $(\%)$ & $\operatorname{Mg}(\%)$ & $\mathrm{S}(\%)$ & $\mathrm{B}(\mathrm{ppm})$ & $\mathrm{N}(\%)$ & $\operatorname{Mg}(\%)$ \\
\hline Biochar (planting hole) & $0.52 \mathrm{~b}^{\mathrm{u}}$ & $0.15 \mathrm{ab}$ & $0.19 \mathrm{~b}$ & $15 \mathrm{bc}$ & $1.78 \mathrm{ab}$ & $0.11 \mathrm{~b}$ \\
\hline Biochar + bokashi (planting hole) & $0.57 \mathrm{ab}$ & $0.15 \mathrm{ab}$ & $0.19 \mathrm{~b}$ & $23 \mathrm{a}$ & $1.86 \mathrm{ab}$ & $0.11 \mathrm{~b}$ \\
\hline Biochar + sawdust (planting hole) & $0.60 \mathrm{a}$ & $0.16 \mathrm{a}$ & $0.23 \mathrm{a}$ & $19 \mathrm{ab}$ & $1.89 \mathrm{ab}$ & $0.11 \mathrm{ab}$ \\
\hline Biochar + bokashi (row) & $0.55 \mathrm{ab}$ & $0.13 \mathrm{bc}$ & $0.19 \mathrm{~b}$ & $13 \mathrm{c}$ & $1.90 \mathrm{a}$ & $0.11 \mathrm{~b}$ \\
\hline Biochar + sawdust (row) & $0.53 \mathrm{ab}$ & $0.14 \mathrm{ab}$ & $0.19 \mathrm{~b}$ & $12 \mathrm{c}$ & $1.90 \mathrm{a}$ & $0.12 \mathrm{ab}$ \\
\hline Sawdust (row) ${ }^{\mathrm{w}}$ & $0.57 \mathrm{ab}$ & $0.16 \mathrm{a}$ & $0.19 \mathrm{~b}$ & $15 \mathrm{bc}$ & $1.69 \mathrm{~b}$ & $0.14 \mathrm{a}$ \\
\hline Soil only & $0.54 \mathrm{ab}$ & $0.12 \mathrm{c}$ & $0.18 \mathrm{~b}$ & $12 \mathrm{c}$ & $1.90 \mathrm{a}$ & $0.13 \mathrm{ab}$ \\
\hline Significance & 0.027 & 0.003 & 0.001 & $<0.001$ & 0.003 & 0.015 \\
\hline Recommended sufficiency range ${ }^{\mathrm{v}}$ & $0.41-0.70$ & $0.13-0.25$ & $0.11-0.16$ & $31-80$ & $1.76-2.00$ & $0.13-0.25$ \\
\hline
\end{tabular}

${ }^{\mathrm{z}}$ Leaves were sampled during the last week of July each year.

${ }^{\mathrm{y}}$ In year 1 , the amendments had no effect on leaf concentrations of $\mathrm{N}(1.94 \%), \mathrm{P}(0.14 \%), \mathrm{Ca}$ $(0.50 \%), \mathrm{Cu}(3.4 \mathrm{ppm}), \mathrm{Fe}(57 \mathrm{ppm}), \mathrm{Mn}(62 \mathrm{ppm})$, or $\mathrm{Zn}(16 \mathrm{ppm})$. In year 2, they had no effect on leaf concentrations of P $(0.16 \%), \mathrm{K}(0.62 \%), \mathrm{Ca}(0.40 \%), \mathrm{S}(0.15 \%), \mathrm{B}(6.8 \mathrm{ppm}), \mathrm{Cu}(2.9 \mathrm{ppm}), \mathrm{Fe}$ (88 ppm), Mn (56 ppm), or Zn (17 ppm).

${ }^{\mathrm{x}}$ The amendments were incorporated in the planting hole $(20 \%$ by volume) or in the entire row $(10 \%$ by volume for the biochar mixes and $20 \%$ by volume for sawdust) of the planting bed.

windustry standard.

${ }^{\mathrm{v}}$ The recommended range for other nutrients include the following: $0.11 \%$ to $0.4 \% \mathrm{P}, 0.41 \%$ to $0.8 \%$ Ca, 5-15 ppm Cu, 60-200 ppm Fe, 30-350 ppm Mn, and 8-30 ppm Zn (Hart et al., 2006).

${ }^{\mathrm{u}}$ Means $(\mathrm{n}=5)$ followed by the same letter within a column are not significantly different, according to Tukey's test $(P \leq 0.05)$. 
Table 3. Effects of soil amendments (biochar, biochar mixed with bokashi or douglas fir sawdust, and sawdust only) on soil organic matter content and available soil nutrients following the first 2 years after planting a new field of 'Duke' northern highbush blueberry in western Oregon. ${ }^{\mathrm{z}, \mathrm{y}}$

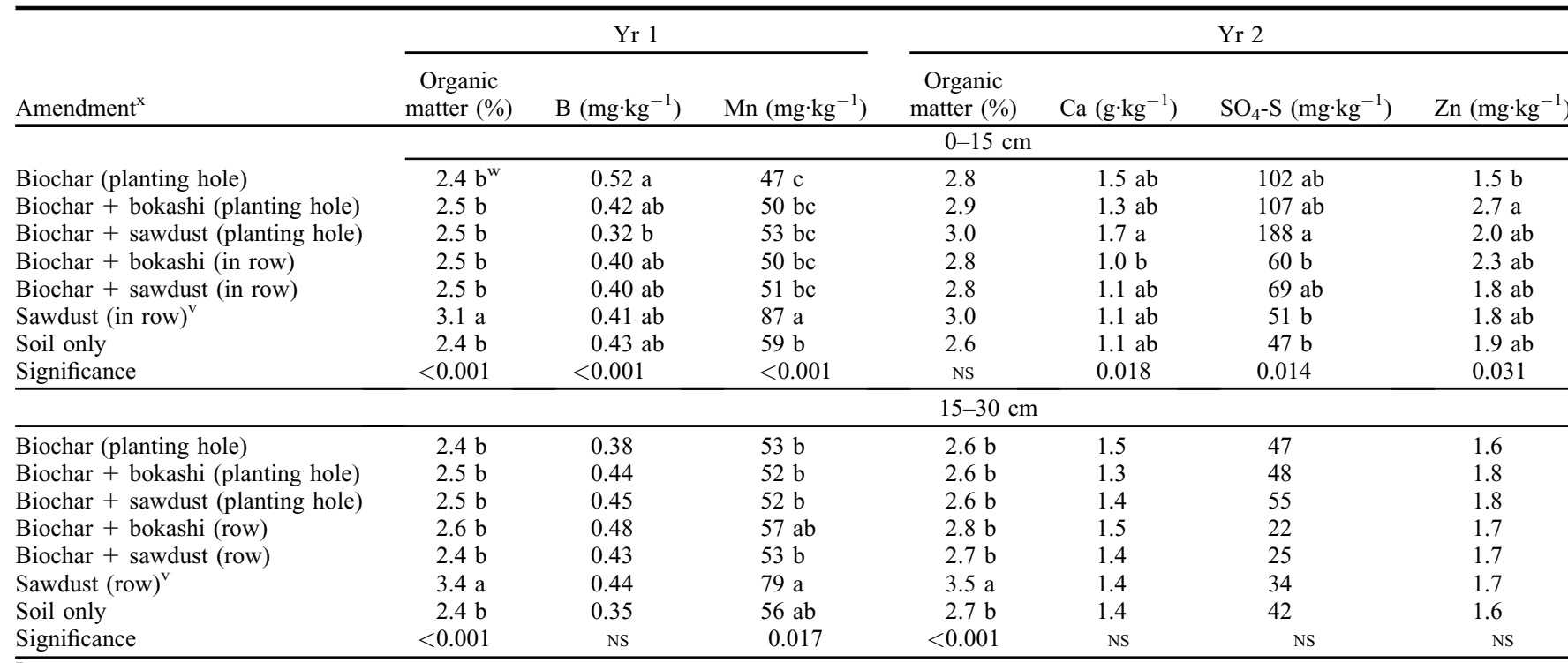

${ }^{2}$ Soil was sampled in October each year at depths of $0-15$ and $15-30 \mathrm{~cm}$.

${ }^{\mathrm{y}}$ The amendments had no effect on other soil nutrients at $0-15$ and $15-30 \mathrm{~cm}$, including the following: $\mathrm{NH}_{4}-\mathrm{N}\left(14.7\right.$ and $13.6 \mathrm{mg} \cdot \mathrm{kg}^{-1}$, respectively, in year 1 and 7.0 and $3.9 \mathrm{mg} \cdot \mathrm{kg}^{-1}$, respectively, in year 2$) ; \mathrm{NO}_{3}-\mathrm{N}\left(7.5\right.$ and $6.7 \mathrm{mg} \cdot \mathrm{kg}^{-1}$, respectively, in year 1 and 16.2 and $2.2 \mathrm{mg} \cdot \mathrm{kg}^{-1}$, respectively, in year 2); P (0.17 and $0.18 \mathrm{~g} \cdot \mathrm{kg}^{-1}$, respectively, in year 1 and 0.15 and $0.16 \mathrm{~g} \cdot \mathrm{kg}^{-1}$, respectively, in year 2$) ; \mathrm{K}\left(0.18 \mathrm{~g} \cdot \mathrm{kg}^{-1}\right.$ at both depths in year 1 and 0.15 and $0.17 \mathrm{~g} \cdot \mathrm{kg}^{-1}$, respectively, in year 2); $\mathrm{Ca}\left(1.6 \mathrm{~g} \cdot \mathrm{kg}^{-1}\right.$ at both depths in year 1$) ; \mathrm{Mg}\left(0.08\right.$ and $0.07 \mathrm{~g} \cdot \mathrm{kg}^{-1}$, respectively, in year 1 and 0.12 and $0.09 \mathrm{~g} \cdot \mathrm{kg}^{-1}$, respectively, in year 2); $\mathrm{SO}_{4}-\mathrm{S}\left(0.05 \mathrm{~g} \cdot \mathrm{kg}^{-1}\right.$ at both depths in year 1$) ; \mathrm{B}\left(0.51\right.$ and $0.55 \mathrm{mg} \cdot \mathrm{kg}^{-1}$, respectively, in year 2$) ; \mathrm{Cu}(1.12$ and 1.11 $\mathrm{mg} \cdot \mathrm{kg}^{-1}$, respectively, in year 1 and 1.38 and $1.35 \mathrm{mg} \cdot \mathrm{kg}^{-1}$, respectively, in year 2); $\mathrm{Mn}$ (36 and $33 \mathrm{mg} \cdot \mathrm{kg}^{-1}$, respectively, in year 2); and $\mathrm{Zn}(1.85$ and $1.78 \mathrm{mg} \cdot \mathrm{kg}^{-1}$, respectively, in year 1 ).

${ }^{\mathrm{x}}$ The amendments were incorporated in the planting hole $(20 \%$ by volume) or in the entire row ( $10 \%$ by volume for the biochar mixes and $20 \%$ by volume for sawdust) of the planting bed.

${ }^{\mathrm{w}}$ Means $(\mathrm{n}=5)$ followed by the same letter within a column are not significantly different at $P \leq 0.05$, according to Tukey's test.

${ }^{\vee}$ Industry standard.

NS = nonsignificant

$(<20 \mathrm{ppm})$ in all but one treatment (i.e., biochar + bokashi in the planting hole in year 1) during both years of the study. Calcium, $\mathrm{Cu}$, and $\mathrm{Fe}$ were also below the recommended range in one or both years, but in no case were these nutrients affected by the soil amendments (see footnotes " $y$ " and " $v$ " in Table 2).

Mycorrhizal colonization. The percentage of roots colonized by mycorrhizal fungi averaged $10 \%$ and was similar among the treatments (data not shown).

Soil fertility, microbial activity, and aggregation. Soil $\mathrm{pH}$ was similar among the treatments and, on average, was 5.5 and 5.6 at a depth of 0 to 15 and 15 to $30 \mathrm{~cm}$, respectively, following the first year after planting, and 5.3 and 5.7, respectively, following the second year. Relative to sawdust in the row and unamended soil, biochar had no effect on soil nutrients other than $\mathrm{SO}_{4}-\mathrm{S}$ in year 2 (Table 3). Soil $\mathrm{SO}_{4}-\mathrm{S}$ was higher at 0 to 15 $\mathrm{cm}$ with biochar + sawdust in the planting hole than with biochar + bokashi in the row, sawdust in the row, or unamended soil. Sawdust in the row, on the other hand, increased soil $\mathrm{Mn}$ in year 1 and soil organic matter content and microbial activity (based on measures of active soil $\mathrm{C}$ and respiration) in both years relative to the other treatments (Tables 3 and 4). In one or both years, sawdust in the row also increased soil aggregation relative to treatments with biochar in the row or in unamended soil (Fig. 3).
There were also a few minor differences in soil nutrients between several of the biochar treatments, including soil B (greater with biochar than with biochar + sawdust in the planting hole at $0-15 \mathrm{~cm}$ ) in year 1 and soil $\mathrm{Ca}$ (greater with biochar + sawdust in the planting hole than with biochar + bokashi in the row at 0-15 cm) and $\mathrm{Zn}$ (greater with biochar + bokashi than with biochar in the planting hole at $0-15 \mathrm{~cm}$ ) in year 2 (Table 3 ). In no case were differences in soil nutrients reflected in the concentrations measured in the leaves (Table 2) or fruit (data not shown).

Plant and soil water relations. Soil water content and stem water potential were similar among the treatments throughout the study and remained $>23 \%$ and $-0.85 \mathrm{MPa}$, respectively (data not shown). However, when irrigation was withheld (day zero was 5 Aug. 2018) from the plants for $10 \mathrm{~d}$ after harvest, soil water content from 0 to $15 \mathrm{~cm}$ was lower in plots with sawdust in the row than with any other treatment except biochar + sawdust in the row (Table 5). Stem water potential was also lower at this point with sawdust in the row than with many of the other treatments, including biochar + sawdust in the row (Table 5).

\section{Discussion}

Amending the soil with biochar in the planting hole or in the row before planting resulted in more vegetative growth in year 1 and higher yields in year 2 than soil only or the standard practices of incorporating sawdust in the row. Growth and yields were normal for the region and similar to a previous study in an organic planting of 'Duke' blueberry (Larco et al., 2013b). Increased plant growth is often reported in soils amended with biochar (De Tender et al., 2016; Headlee et al., 2014; Méndez et al., 2013). However, more growth with biochar does not always result in higher yields (Eyles et al., 2015). For example, Vaccari et al. (2015) found that adding biochar to the soil increased growth in tomato (Solanum lycopersicum L.) relative to soil only but had no effect on yield. Likewise, Safaei et al. (2019) reported that biochar increased trunk diameter and the number of shoots in a new planting of apple [Malus $\times$ sylvestris (L.) Mill. var. domestica (Borkh.) Mansf.], but again, it did not increase yield. In our case, fruit production, which first occurred during the second year after planting (industry standard), was highly correlated to total plant biomass at the end of the previous year. This was expected because we removed floral buds and determined yield based on the vigor of each plant. In contrast, Zhang et al. (2020) determined that biochar produced by slow pyrolysis at $450{ }^{\circ} \mathrm{C}$ using wood waste collected from local furniture factories had no effect on growth or yield of northern highbush blueberry in China (although it increased vitamin $\mathrm{C}$ and reduced titratable acidity in the fruit). 
Table 4. Effects of soil amendments (biochar, biochar mixed with bokashi or douglas fir sawdust, and sawdust only) on microbial soil activity following the first 2 years after planting a new field of 'Duke' northern highbush blueberry in western Oregon.

\begin{tabular}{|c|c|c|c|c|c|c|}
\hline \multirow[b]{3}{*}{ Amendment $^{2}$} & \multicolumn{3}{|c|}{ Yr 1} & \multicolumn{3}{|c|}{ Yr 2} \\
\hline & \multirow{2}{*}{$\begin{array}{c}\text { Active soil } \\
\mathrm{C}\left(\mathrm{mg} \cdot \mathrm{kg}^{-1}\right)\end{array}$} & \multicolumn{2}{|c|}{ Soil respiration $\left(\mathrm{mmol} \cdot \mathrm{m}^{-2} \cdot \mathrm{s}^{-1}\right)$} & \multirow{2}{*}{$\begin{array}{l}\text { Active soil } \\
\mathrm{C}\left(\mathrm{mg} \cdot \mathrm{kg}^{-1}\right)\end{array}$} & \multicolumn{2}{|c|}{ Soil respiration $\left(\mathrm{mmol} \cdot \mathrm{m}^{-2} \cdot \mathrm{s}^{-1}\right)$} \\
\hline & & $24 \mathrm{~h}$ & $72 \mathrm{~h}$ & & $24 \mathrm{~h}$ & $72 \mathrm{~h}$ \\
\hline Biochar + bokashi (planting hole) & $11.8 \mathrm{~b}$ & $44 \mathrm{~b}$ & $28 \mathrm{~b}$ & $10.2 \mathrm{~b}$ & $30 \mathrm{~b}$ & $19 \mathrm{~b}$ \\
\hline Biochar + sawdust (planting hole) & $11.2 \mathrm{~b}$ & $41 \mathrm{~b}$ & $28 \mathrm{~b}$ & $10.4 \mathrm{~b}$ & $22 \mathrm{~b}$ & $14 \mathrm{~b}$ \\
\hline Biochar + bokashi (row) & $8.7 \mathrm{~b}$ & $32 \mathrm{~b}$ & $21 \mathrm{~b}$ & $8.1 \mathrm{~b}$ & $20 \mathrm{~b}$ & $13 \mathrm{~b}$ \\
\hline Biochar + sawdust (row) & $9.2 \mathrm{~b}$ & $34 \mathrm{~b}$ & $21 \mathrm{~b}$ & $7.2 \mathrm{~b}$ & $21 \mathrm{~b}$ & $13 \mathrm{~b}$ \\
\hline Significance & $<0.001$ & $<0.001$ & $<0.001$ & $<0.001$ & $<0.001$ & $<0.001$ \\
\hline
\end{tabular}

${ }^{\mathrm{z}}$ The amendments were incorporated in the planting hole ( $20 \%$ by volume) or in the entire row (10\% by volume for the biochar mixes and $20 \%$ by volume for sawdust) of the planting bed.

${ }^{\mathrm{y}}$ Means $(\mathrm{n}=5)$ followed by the same letter within a column are not significantly different at $P \leq 0.05$, according to Tukey's test.

${ }^{\mathrm{x}}$ Industry standard.

We should point out that adding sawdust to soil resulted in several potential benefits in the planting that were absent in the biochar treatments or soil alone, including increased organic matter content, greater active $\mathrm{C}$ and microbial activity, and a higher percentage of wet stable aggregates in the soil. However, amending soil with sawdust also led to low $\mathrm{N}$
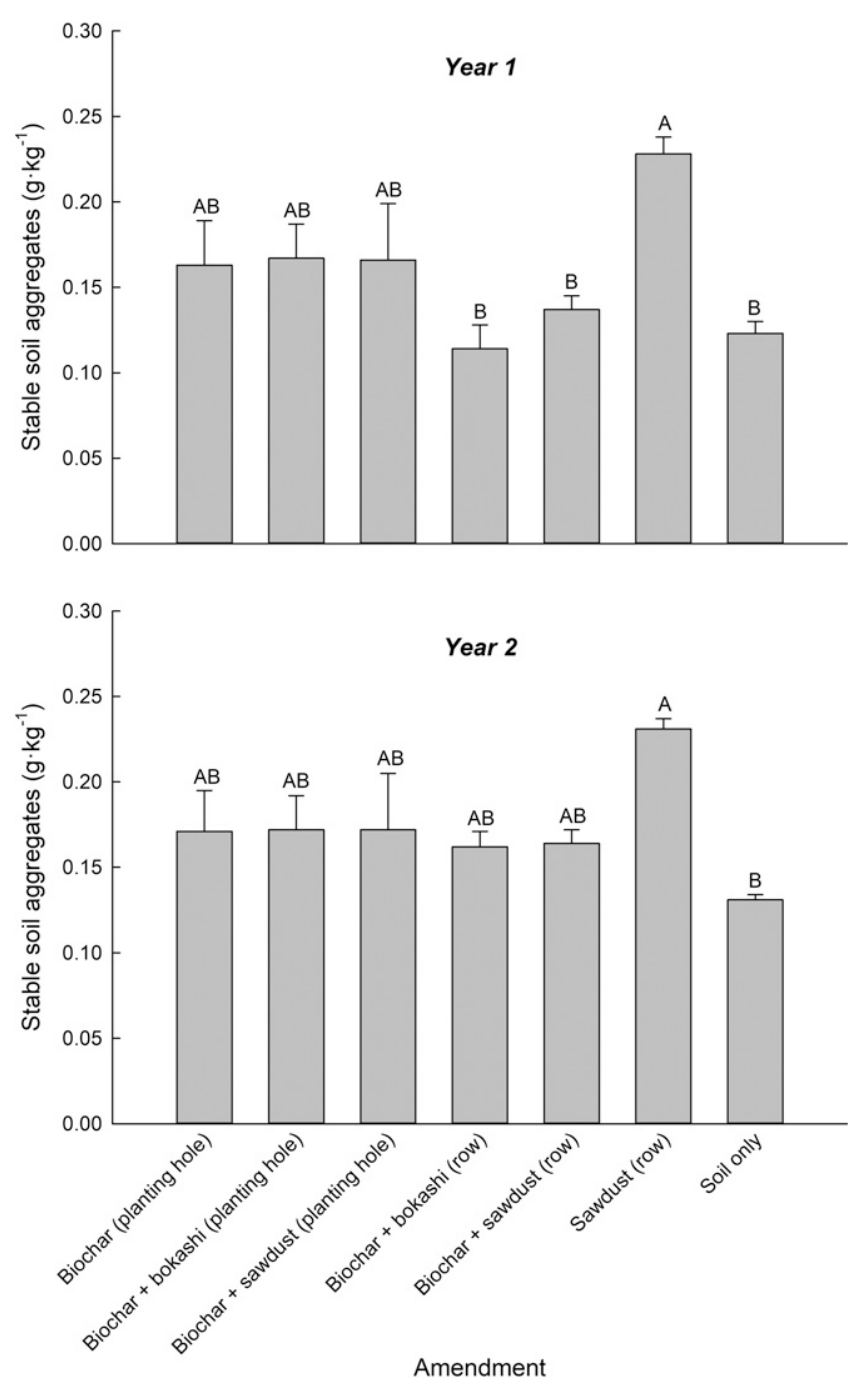

Fig. 3. Effects of soil amendments (biochar, biochar mixed with bokashi or douglas fir sawdust, and sawdust only) on soil aggregation following the first 2 years after planting a new field of 'Duke' northern highbush blueberry in western Oregon. The amendments were incorporated in the planting hole $(20 \%$ by volume) or in the entire row $(10 \%$ by volume for the biochar mixes and $20 \%$ by volume for sawdust) of the planting bed. Incorporation of sawdust in the row is the industry standard. Means $(\mathrm{n}=5)$ with the same letter above the bars from a given year are not significantly different, according to Tukey's test $(P \leq 0.05)$. Error bars represent 1 SE. in the plants, which likely reduced growth and yield relative to biochar. In fact, sawdust reduced growth (year 1) and yield even when it was mixed in the planting hole with biochar. Nitrogen is commonly immobilized by soil microbes during decomposition of woody materials such as bark or sawdust (Bünemann et al., 2006; Cesarano et al., 2017; White, 2006). Biochar, in contrast, is a recalcitrant $\mathrm{C}$ source and, therefore, has a minimal effect on soil $\mathrm{N}$ immobilization (Nelissen et al., 2015). Although this was not the case in the present study, biochar has also been shown to increase soil water holding capacity and improve crop production under adverse soil conditions such as high salinity and drought (Haider et al., 2015; Thomas et al., 2013). Bark and sawdust, on the other hand, increase soil drainage, which, depending on the frequency of rain or irrigation, could reduce water uptake and lead to water stress in blueberry (White, 2006).

The most prohibitive factor to wide-scale use of biochar in agriculture is the cost (Campbell et al., 2018). The cost of the biochar used in the present study was $\$ 76 / \mathrm{m}^{3}$. Douglas fir sawdust, in contrast, was $\$ 9.20 / \mathrm{m}^{3}$. In Oregon, the total estimated cost of incorporating douglas fir sawdust into the row before planting was $\$ 4350 /$ ha in 2011 (Julian et al., 2012). In comparison, the cost of amending the planting hole with $4 \mathrm{~L}$ of biochar was only $\$ 1980 /$ ha. Therefore, even after increased labor costs are considered $(\$ 1050 / \mathrm{ha})$, growers could reduce costs by replacing sawdust with biochar and, at the same time, increase returns by improving early fruit production. Additional savings could be obtained by producing biochar on-site using prunings and other waste from blueberry fields (Liu et al., 2021). It is unclear whether biochar would be beneficial beyond the second season, but if it was, the common practice of adding organic matter to the soil with a sawdust mulch every few years could be eliminated, reducing the production costs of blueberry even further. Biochar could also lead to a long-term, stable increase of soil organic matter under weed mat mulch, which is currently the most common type of mulch used by the blueberry industry. Normally, soil organic matter decreases over time under weed mat (Davis and Strik, 2021; 
Table 5. Effects of soil amendments (biochar, biochar mixed with bokashi or douglas fir sawdust, and sawdust only) on plant and soil water relations before and after irrigation was withheld for $10 \mathrm{~d}$ in a new planting of 'Duke' northern highbush blueberry in western Oregon. ${ }^{\mathrm{Z}}$

\begin{tabular}{|c|c|c|c|c|c|c|}
\hline \multirow[b]{3}{*}{ Amendment ${ }^{\mathrm{x}}$} & \multicolumn{3}{|c|}{ Fully irrigated (day 0$)^{\mathrm{y}}$} & \multicolumn{3}{|c|}{ After $10 \mathrm{~d}$ without irrigation ${ }^{\mathrm{y}}$} \\
\hline & \multicolumn{2}{|c|}{ Soil water content $(\%)$} & \multirow{2}{*}{$\begin{array}{c}\text { Stem water } \\
\text { potential }(\mathrm{MPa})\end{array}$} & \multicolumn{2}{|c|}{ Soil water content $(\%)$} & \multirow{2}{*}{$\begin{array}{c}\text { Stem water } \\
\text { potential }(\mathrm{MPa})\end{array}$} \\
\hline & $0-15 \mathrm{~cm}$ & $0-30 \mathrm{~cm}$ & & $0-15 \mathrm{~cm}$ & $0-30 \mathrm{~cm}$ & \\
\hline Biochar (planting hole) & 28.3 & 27.2 & -0.83 & $21.4 \mathrm{ab}^{\mathrm{W}}$ & 24.8 & $-0.88 \mathrm{a}$ \\
\hline Biochar + bokashi (planting hole) & 27.0 & 27.7 & -0.80 & $23.9 \mathrm{ab}$ & 25.9 & $-0.91 \mathrm{a}$ \\
\hline Biochar + sawdust (planting hole) & 25.8 & 27.0 & -0.77 & $21.5 \mathrm{ab}$ & 24.7 & $-0.94 \mathrm{ab}$ \\
\hline Biochar + bokashi (row) & 25.6 & 28.3 & -0.80 & $21.4 \mathrm{ab}$ & 26.7 & $-0.95 \mathrm{ab}$ \\
\hline Biochar + sawdust (row) & 27.4 & 26.0 & -0.79 & $19.6 \mathrm{bc}$ & 21.2 & $-0.91 \mathrm{a}$ \\
\hline Sawdust (row) ${ }^{\mathrm{v}}$ & 23.5 & 26.9 & -0.80 & $16.4 \mathrm{c}$ & 21.4 & $-1.03 \mathrm{~b}$ \\
\hline Soil only & 28.6 & 27.2 & -0.76 & $24.7 \mathrm{a}$ & 22.4 & $-0.89 \mathrm{a}$ \\
\hline Significance & NS & NS & NS & 0.039 & NS & 0.005 \\
\hline
\end{tabular}

${ }^{\mathrm{z}}$ Irrigation was withheld after fruit harvest in the second growing season. There was no rain during this period.

${ }^{\mathrm{y}}$ Measurements were made at midday.

${ }^{\mathrm{x}}$ The amendments were incorporated in the planting hole $(20 \%$ by volume) or in the entire row ( $10 \%$ by volume for the biochar mixes and $20 \%$ by volume for sawdust) of the planting bed.

${ }^{\text {w} M e a n s ~}(\mathrm{n}=5)$ followed by the same letter within a column are not significantly different at $P \leq 0.05$, according to Tukey's test.

${ }^{\mathrm{v}}$ Industry standard.

NS $=$ nonsignificant

Strik et al., 2019), but because biochar is recalcitrant, it would persist and continue to provide benefits to the plants for many years.

Another major concern with using biochar, particularly in blueberry, is high $\mathrm{pH}$. Biochar is known to act as a liming agent (Trippe et al., 2015). However, we did not find this to be the case in this or our previous study with biochar for blueberry (Sales et al., 2020). In both cases, the biochar was produced from wood debris obtained from mixed conifer species. Increases in soil $\mathrm{pH}$ are dependent on the chemical composition of the biochar and buffering capacity of the soil (Uchimiya and Bannon, 2013). Biochars produced from woody materials are usually low in ash content and, therefore, tend to have little to no effect on soil pH (Singh et al., 2010). In contrast, those produced from products with high amounts of $\mathrm{K}$ and other nutrients, such as food waste and animal manures, are high in ash and often increase soil pH (Singh et al., 2010); these biochars may be less suitable for blueberry. Ash content is also affected by the temperature and duration of pyrolysis (Cao and Harris, 2010). Growers interested in using biochar in blueberry should test it on a batch-by-batch basis and ensure that it is high in $\mathrm{C}$ and low in ash or has a low $\mathrm{CaCO}_{3}$ equivalence.

The concentration of $\mathrm{Mg}$ in the leaves was low in each of the treatments with biochar during the second year after planting, suggesting that biochar could lead eventually to Mg deficiency in blueberry. Biochar also resulted in lower concentrations of $\mathrm{Mg}$ in the leaves of corn (Zea mays L.) and sesame (Sesamum indicum L.) (Syuhada et al., 2016; Wacal et al., 2019). In both studies, reduced Mg concentrations were associated with increased concentrations of $\mathrm{K}$ in the leaves. However, in the present study, the concentration of $\mathrm{K}$ in the leaves was similar between treatments with or without biochar and within the recommended range for blueberry. Magnesium deficiency causes the outer portion of blueberry leaves to turn yellow or red, while the middle of the leaves remains green (Polashock et al., 2017).
Symptoms usually develop later in the season on leaves located at the base of the shoots. Such symptoms did not occur in the present study. If needed, $\mathrm{Mg}$ deficiency could be easily corrected in plants with biochar by applying $\mathrm{MgSO}_{4}$ (Hart et al., 2006).

Regardless of biochar, plants from each treatment had low concentrations of $B$ in the leaves. Boron deficiency causes dieback of the shoot tips in blueberry and is a fairly common problem in northwestern United States and British Columbia, Canada (Hart et al., 2006). Typically, when plants are deficient, leaves located close to aborted shoot tips will cup and develop a mottled chlorosis pattern; leaf and fruit buds may fail to develop on severely affected plants (Polashock et al., 2017). Again, we saw no evidence of B deficiency in the present study; however, foliar or soil applications of B fertilizer such as boric acid or sodium borate would be highly recommended when the concentration of $\mathrm{B}$ in the leaves is $<20$ ppm (Hart et al., 2006).

As mentioned earlier, we previously found that adding bokashi to biochar improved growth in blueberry relative to using biochar alone (Sales et al., 2020). This was not the case in the present study. This time, whether biochar was mixed with bokashi and incorporated into the planting hole or row, it resulted in more-or-less the same amount of plant growth and yield as treatments with sawdust in the row or soil only. In this case, plants were grown in a fertile silty loam soil and fertigated weekly with N. In contrast, plants in the previous study were grown in a sandy loam soil under low $\mathrm{N}$ conditions and, therefore, responded positively to additional nutrients in the bokashi.

We also discovered previously that biochar or biochar + bokashi resulted in a considerable increase in root colonization by ericoid mycorrhizal fungi (Sales et al., 2020). In the previous study, the percentage of roots colonized by mycorrhizal fungi was $56 \%$ to $91 \%$ in plants grown in soil with biochar or biochar + bokashi but $\leq 10 \%$ in those grown in unamended soil. In contrast, colonization was approximately $10 \%$ in each treatment in the present study and was unaffected by either biochar or biochar + bokashi. Colonization is often lower when blueberry plants are grown in fertile soils (Scagel and Yang, 2005; Yang et al., 2002), which may explain why mycorrhizal response to biochar was so different between the present and previous study. In a survey of 55 commercial blueberry fields in Oregon, Scagel and Yang (2005) found that mycorrhizal colonization ranged from $0.5 \%$ to $44 \%$ of the total root length, with lower colonization generally occurring at sites with higher concentrations of $\mathrm{NH}_{4}-\mathrm{N}$ in the soil.

\section{Conclusions}

Based on the results of this study, biochar appears to have considerable potential for improving growth and fruit production in highbush blueberry. The most cost-effective method to apply biochar in the present study was adding it to the hole at planting; however, this method was somewhat laborious and difficult to apply consistently. Alternatively, biochar could be applied in a narrow band on the row (e.g., 10-20 cm wide) and incorporated into the soil before shaping the beds. Doing so would require slightly more biochar but would reduce labor costs considerably. More research is needed to identify the best method to apply the biochar. Studies are also needed to determine whether biochar has any positive long-term effects on fruit production and mineral nutrition in blueberry.

\section{Literature Cited}

Amoakwah, E., K.A. Frimpong, D. Okae-Anti, and E. Arthur. 2017. Soil water retention, air flow, and pore structure characteristics after corn cob biochar application to a tropical sandy loam. Geoderma 307:189-197, https://doi.org/10.1016/ j.geoderma.2017.08.025.

Bray, H.R. and L.T. Kurtz. 1945. Determination of total, organic, and available forms of phosphorus in soils. Soil Sci. 59:39-45. 
Bryla, D.R. 2011. Crop evapotranspiration and irrigation scheduling in blueberry, p. 167-186. In: G. Gerosa (ed.). Evapotranspiration-from measurements to agricultural and environmental applications. Intech, Rijeka, Croatia, https://doi. org/10.5772/18311

Bryla, D.R. and B.C. Strik. 2007. Effects of cultivar and plant spacing on the seasonal water requirements of highbush blueberry. J. Amer. Soc. Hort. Sci. 132:270-277, https://doi.org/ 10.21273/JASHS.132.2.270.

Bünemann, E.K., G.D. Schwenke, and L. Van Zwieten. 2006. Impact of agricultural inputs on soil organisms - a review. Austral. J. Soil Res. 44:379-406, https://doi.org/10.1071/SR05125.

Campbell, R., N. Anderson, D. Daugaard, and H. Naughton. 2018. Financial viability of biofuel and biochar production from forest biomass in face of market price volatility and uncertainty. Appl. Energy 230:330-343, https://doi.org/ 10.1016/j.apenergy.2018.08.085.

Cao, X. and W. Harris. 2010. Properties of dairymanure-derived biochar pertinent to its potential use in remediation. Bioresour. Technol. 101: 5222-5228, https://doi.org/10.1016/j.biortech. 2010.02 .052 .

Cesarano, G., F. De Fillipis, A. la Storia, F. Scala, and G. Bonanomi. 2017. Organic amendment type and application frequency affect crop yields, soil fertility and microbiome composition. Appl. Soil Ecol. 120:254-264, https://doi. org/10.1016/j.apsoil.2017.08.017.

Crane-Droesch, A., S. Abiven, S. Jefery, and M.S. Torn. 2013. Heterogeneous global crop yield response to biochar: A meta-regression analysis. Environ. Res. Lett. 8:044049, https://doi. org/10.1088/1748-9326/8/4/044049.

Dahnke, W.C. and G.V. Johnson. 1990. Testing soils for available nitrogen, p. 127-140. In: R.L. Westerman (ed.). Soil testing and plant analysis. 3rd ed. Soil Sci. Soc. Amer., Madison, WI, https:// doi.org/10.2136/sssabookser3.3ed.

Davis, A.J. and B.C. Strik. 2021. Long-term organic production systems in northern highbush blueberry: Placing weed mat over existing organic mulches and changing to nitrogen-only fertilizer sources increased yield. HortScience 56:897908, https://doi.org/10.21273/HORTSCI15908-21.

De Tender, C.A., J. Debode, B. Vandecastelle, T. D'Hose, P. Cremelie, A. Haegeman, T. Ruttink, P. Dawyndt, and M. Maes. 2016. Biological, physiochemical and plant health responses in lettuce and strawberry in soil or peat amended with biochar. Appl. Soil Ecol. 107:1-12, https://doi. org/10.1016/j.apsoil.2016.05.001.

Duku, M.H., S. Gu, and E.B. Hagan. 2011. Biochar production potential in Ghana: A review. Renew. Sustain. Energy Rev. 15:3539-3551, https://doi.org/10.1016/j.rser.2011.05.010.

Eyles, A., S.A. Bound, G. Oliver, R. Corkrey, M. Hardie, S. Green, and D.C. Close. 2015. Impact of biochar amendment on the growth, physiology and fruit of a young commercial apple orchard. Trees (Berl.) 29:1817-1826, https://doi.org/10.1007/s00468-015-1263-7.

Gavlak, R., D. Horneck, and R.O. Miller. 2005. Soil, plant and water reference methods for the western region. 3rd ed. Western Region Extension Publication (WREP-125). WERA-103 Technical Committee. 16 Sept. 2021. <https://www.naptprogram. org/files/napt/western-states-method-manual-2005. pdf $>$.

Giovannetti, M. and B. Mosse. 1980. An evaluation of techniques for measuring vesicular arbuscular mycorrhizal infection in roots. New Phytol. 84:489-500, https://doi.org/10.1111/ j.1469-8137.1980.tb04556.x.
Glaser, B., L. Haumaier, G. Guggenberger, and W. Zech. 2001. The 'Terra Preta' phenomenon: A model for sustainable agriculture in the humid tropics. Naturwissenschaften 88:37-41, https:// doi.org/10.1007/s001140000193.

Gonzaga, M.I.S., C.L. Mackowiak, N.B. Comerford, E.F. Moline, J.P. Shirley, and D.V. Guimaraes. 2017. Pyrolysis methods impact biosolidsderived biochar composition, maize growth, and nutrition. Soil Tillage Res. 165:59-65, https:// doi.org/10.1016/j.still.2016.07.009.

Haider, G., H. Koyro, F. Azam, D. Steffens, C. Muller, and C. Kammann. 2015. Biochar but not humic acid product amendment affected maize yields via improving plant-soil moisture relations. Plant Soil 395:141-157, https://doi. org/10.1007/s11104-014-2294-3.

Hart, J., B. Strik, L. White, and W. Yang. 2006. Nutrient management for blueberries in Oregon. Ore. St. Univ. Ext. Serv. Publ. EM 8918. 1 Feb. 2021. <http://ir.library.oregonstate.edu/xmlui/ bitstream/handle/1957/20444/em8918.pdf>.

Headlee, W., L. Brewer, and C. Hall. 2014. Biochar as a substitute for vermiculite in potting mix for hybrid poplar. BioEnergy Res. 7:120-131, https://doi.org/10.1007/s12155-013-9355-y.

Herath, H.M.S.K., M. Camps-Arbestain, and M. Hedley. 2013. Effect of biochar on soil physical properties in two contrasting soils: An Alfisol and an Andisol. Geoderma 209-210:188-197, https://doi.org/10.1016/j.geoderma.2013.06.016>.

Horneck, D., J. Hart, R. Stevens, S. Petrie, and J. Altland. 2004. Acidifying soil for crop production west of the Cascade Mountains (western Oregon and Washington). Ore. St. Univ. Ext. Serv. Publ. EM 8857-E. 17 Sept. 2021. $<$ https://catalog.extension.oregonstate.edu/sites/ catalog/files/project/pdf/em8857.pdf $>$.

Hussain, M., M. Farooq, A. Nawaz, A. Al-Sadi, Z. Solaiman, S. Alghamdi, U. Ammara, Y. Ok, and K. Siddique. 2017. Biochar for crop production: Potential benefits and risks. J. Soils Sediments 17:685-716, https://doi.org/10.1007/ s11368-016-1360-2.

Jones, J.B. and V.W. Case. 1990. Sample, handling, and analyzing plant tissue samples, $\mathrm{p}$. 389-427. In: R.L. Westerman (ed.). Soil testing and plant analysis, vol. 3, 3rd ed. Soil Sci. Soc. Amer., Madison, WI, https://doi.org/10.2136/ sssabookser3.3ed.

Julian, J.W., B.C. Strik, H.O. Larco, D.R. Bryla, and D.M. Sullivan. 2012. Costs of establishing organic northern highbush blueberry: Impacts of planting method, fertilization, and mulch type. HortScience 47:866-873, https://doi.org/ 10.21273/HORTSCI.47.7.866.

Larco, H., B.C. Strik, D.R. Bryla, and D.M. Sullivan. 2013a. Mulch and fertilizer management practices for organic production of highbush blueberry. I: Plant growth and allocation of biomass during establishment. HortScience 48:1250-1261, https:// doi.org/10.21273/HORTSCI.48.10.1250.

Larco, H., B.C. Strik, D.R. Bryla, and D.M. Sullivan. 2013b. Mulch and fertilizer management practices for organic production of highbush blueberry. II. Impact on plant and soil nutrients during establishment. HortScience 48:1484-1495, https://doi.org/10.21273/HORTSCI.48.12.1484.

Lehmann, J. and S. Joseph. 2009. Biochar for environmental management. Science and technology. Earthscan, Sterling, VA, https://doi.org/ 10.4324/9781849770552.

Lehmann, J., M. Rillig, J. Thies, C. Masiello, W. Hockaday, and D. Crowley. 2011. Biochar effects on soil biota - a review. Soil Biol. Biochem. 43:1812-1836, https://doi.org/10.1016/j. soilbio.2011.04.022.
Liu, H., S. Qin, R. Sirohi, V. Ahluwalia, Y. Zhou, R. Sindhu, P. Binod, R. Rani Singhnia, A. Kumar Patel, A. Juneja, D. Kumar, Z. Zhang, J. Kumar, M.J. Taherzadeh, and M. Kumar Awasthi. 2021. Sustainable blueberry waste recycling towards biorefinery strategy and circular bioeconomy: A review. Bioresour. Technol. 332:125181, https:// doi.org/10.1016/j.biortech.2021.125181.

Luo, Y., Q. Lin, M. Durenkamp, A. Dungait, and P. Brookes. 2017. Soil priming effects following substrates addition to biochar-treated soils after 431 days of pre-incubation. Biol. Fertil. Soils 53:315-326, https://doi.org/10.1007/s00 374-017-1180-6.

Major, J., J. Lehmann, M. Rondon, and C. Goodale. 2010. Fate of soil-applied black carbon: Downward migration, leaching and soil respiration. Glob. Change Biol. 16:1366-1370, https:// doi.org/10.1111/j.1365-2486.2009.02044.x.

McGeehan, S.L. and D.V. Naylor. 1988. Automated instrumental analysis of carbon and nitrogen in plant and soil samples. Commun. Soil Sci. Plant Anal. 19:493-505, https://doi. org/10.1080/00103628809367953.

McGonigle, T.P., M.H. Miller, D.G. Evans, G.L. Fairchild, and J.A. Swan. 1990. A new method which gives an objective measure of colonization of roots by vesicular arbuscular mycorrhizal fungi. New Phytol. 115:495-501, https:// doi.org/10.1111/j.1469-8137.1990.tb00476.x.

Mehlich, A. 1984. Mehlich 3 soil test extractant: A modification of Mehlich-2 extractant. Commun. Soil Sci. Plant Anal. 15:1409-1416, https://doi. org $/ 10.1080 / 00103628409367568$.

Méndez, A., A.M. Tarquis, A. Saa-Requejo, F. Guerrero, and G. Gascó. 2013. Influence of pyrolysis temperature on composted sewage sludge biochar priming effect in a loamy soil. Chemosphere 93:668-676, https://doi.org/ 10.1016/j.chemosphere.2013.06.004.

Moebius-Clune, B.N., D.J. Moebius-Clune, B.K. Gigino, O.J. Idowu, R.R. Schindelbeck, A.J. Ristow, H.M. van Es, J.E. Thies, H.A. Shayler, M.B. McBride, K.S.M. Kurtz, D.W. Wolfe, and G.S. Abawi. 2016. Comprehensive assessment of soil health. The Cornell framework, 3rd ed. Cornell University, Geneva, NY. 3 Nov. 2021. <http:// www.css.cornell.edu/extension/soil-health/ manual.pdf $>$.

Molnár, M., E. Vaszita, E. Farkas, E. Ujaczki, I. Fekete-Kertész, M. Tolner, C. Klebercz, C. Kirchkeszner, K. Gruiz, N. Uzinger, and V. Feigl. 2016. Acidic sandy soil improvement with biochar - a microcosm study. Sci. Total Environ. 563:855-865, https://doi.org/10.1016/ j.scitotenv.2016.01.091.

Mukome, F.N.D., X. Zhang, L.C.R. Silva, J. Six, and S.J. Parikh. 2013. Use of chemical and physical characteristics to investigate trends in biochar feedstocks. J. Agr. Food Chem. 61:2196-2204, https://doi.org/10.1021/jf3049142.

Nelissen, V., T. Rutting, D. Huygens, G. Ruysschaert, and P. Boeckx. 2015. Temporal evolution of biochar's impact on soil nitrogen processes $-\mathrm{a}^{15} \mathrm{~N}$ tracing study. Glob. Change Biol. Bioenergy 7:635-645, https://doi.org/10.1111/gcbb.12156.

Nemati, M., F. Simard, J. Fortin, and J. Beaudoin. 2014. Potential use of biochar in growing media. Vadose Zone J. 14:1-8, https://doi.org/ 10.2136/vzj2014.06.0074.

Ogden, C.B., H.M. van Es, and R.R. Schindelbeck. 1997. Miniature rain simulator for measurement of infiltration and runoff. Soil Sci. Soc. Amer. J. 61:1041-1043, https://doi.org/10.2136/sssaj1997. 03615995006100040008x.

Polashock, J.J., F.L. Caruso, A.L. Averill, and A.C. Schilder. 2017. Compendium of blueberry, cranberry, and lingonberry diseases and 
pests. 2nd ed. APS Press, Amer. Phytopathol. Soc., St. Paul, MN, https://doi.org/10.1094/ 9780890545386.

Retamales, J.B. and J.F. Hancock. 2018. Blueberries. 2nd ed. CABI, Cambridge, MA.

Safaei, K.M., G. Zhang, A. Fatemi, R. Kiefer, K. Maddah, M. Baqar, M.P. Zakaria, and G. Li. 2019. Impact of biochar and compost amendment on soil quality, growth and yield of a replanted apple orchard in a 4-year field study. J. Sci. Food Agr. 99:1862-1869, https://doi. org/10.1002/jsfa.9380.

Sales, B.K., D.R. Bryla, K.M. Trippe, J.E. Weiland, C.F. Scagel, B.C. Strik, and D.M. Sullivan. 2020. Amending sandy soil with biochar promotes plant growth and root colonization by mycorrhizal fungi in highbush blueberry. HortScience 55:353-361, https://doi.org/10.21273/HORTSCI 14542-19.

Scagel, C.F. and W.Q. Yang. 2005. Cultural variation and mycorrhizal status of blueberry plants in NW Oregon commercial production fields. Intl. J. Fruit Sci. 5:85-111, https://doi.org/ 10.1300/J492v05n02_10.

Shulte, E.E. and B.G. Hopkins. 1996. Estimation of soil organic matter by weight loss-on-ignition, $p$. 21-31. In: F.R. Magdoff, M.A. Tabatabai, and E.A. Hanlon, Jr. (eds.). Soil organic matter: Analysis and interpretation. Soil Sci. Soc. Amer., Madison, WI, https://doi.org/10.2136/sssaspec pub46.

Singh, B., B.P. Singh, and A.L. Cowie. 2010. Characterization and evaluation of biochars for their application as a soil amendment. Austral. J. Soil Res. 48:516-525, https://doi.org/10.1071/SR10 058.

Sohi, S.P., E. Krull, E. Lopez-Capel, and R. Bol. 2010. A review of biochar and its use and function in soil. Adv. Agron. 105:47-82, https://doi. org/10.1016/S0065-2113(10)05002-9.

Soil Survey Staff. 2014. Keys to soil taxonomy. 12th ed. U.S. Dept. Agr., Natural Resources Conservation Serv., Washington, D.C.

Spokas, K., J. Baker, and D. Reicosky. 2010. Ethylene: Potential key for biochar amendment impacts. Plant Soil 331:443-452, https://doi. org/10.1007/s11104-010-0359-5.

Strik, B. and G. Buller. 2005. The impact of early cropping on subsequent growth and yield of highbush blueberry in the establishment years at two planting densities is cultivar dependant. HortScience 40:1998-2001, https://doi.org/ 10.21273/HORTSCI.40.7.1998.

Strik, B.C., A. Vance, D.R. Bryla, and D.M. Sullivan. 2019. Organic production systems in northern highbush blueberry: II. Impact of planting method, cultivar, fertilizer, and mulch on leaf and soil nutrient concentrations and relationships with yield from planting through maturity. HortScience 54:1777-1794, https:// doi.org/10.21273/HORTSCI14197-19.

Strik, B.C., A.J. Vance, and C.E. Finn. 2017. Northern highbush blueberry cultivars differed in yield and fruit quality in two organic production systems from planting to maturity. HortScience 52:844-851, https://doi.org/ 10.21273/HORTSCI1 1972-17.

Syuhada, A.B., J. Shamshuddin, C.I. Fauziah, A.B. Rosenani, and A. Arifin. 2016. Biochar as a soil amendment: Impact on chemical properties and corn nutrient uptake in a Podzol. Can. J. Soil Sci. 96:400-412, https://doi.org/10.1139/ cjss-2015-0044.

Thomas, S.C., S. Frye, N. Gale, M. Garmon, R. Launchbury, N. Machado, S. Melamed, J. Murray, A. Petroff, and C. Winsborough. 2013. Biochar mitigates negative effects of salt additions on two herbaceous plant species. J. Environ. Mgt. 129:62-68, https://doi.org/10.1016/j. jenvman.2013.05.057.

Trippe, K.M., S.M. Griffith, G.M. Banowetz, and G.W. Whitaker. 2015. Changes in soil chemistry following wood and grass biochar amendments to an acidic agricultural production soil. Agron. J. 107:1440-1446, https://doi.org/10.2134/agronj 14.0593.

Uchimiya, M. and D.I. Bannon. 2013. Solubility of lead and copper in biochar-amended small arms range soils: Influence of soil organic carbon and pH. J. Agr. Food Chem. 61:7679-7688, https:// doi.org/10.1021/jf401481x.
Vaccari, F.P., A. Maienza, F. Miglietta, S. Baronti, S. Di Lonardo, L. Giagnoni, A. Lagomarsino, A. Pozzi, E. Pusceddu, R. Ranier, G. Valboa, and L. Genesio. 2015. Biochar stimulates plant growth but no fruit yield of processing tomato in a fertile soil. Agr. Ecosyst. Environ. 207:163170, https://doi.org/10.1016/j.agee.2015.04.015.

Wacal, C., N. Ogata, D. Basalirwa, T. Handa, D. Sasagawa, R. Acidri, T. Ishigaki, M. Kato, T. Masunaga, S. Yamamoto, and E. Nishihara. 2019. Growth, seed yield, mineral nutrients and soil properties of sesame (Sesamum indicum L.) as influenced by biochar addition on upland field converted from paddy. Agronomy (Basel) 9:55, https://doi.org/10.3390/agronomy9020055.

Weil, R.R., K.R. Islam, M.A. Stine, J.B. Gruber, and S.E. Samson-Liebig. 2003. Estimating active carbon for soil quality assessment: A simplified method for laboratory and field use. Amer. J. Altern. Agr. 18:3-17, https://doi.org/ 10.1079/AJAA200228.

White, L. 2006. The effect of pre-plant incorporation with sawdust, sawdust mulch, and nitrogen fertilizer rate on soil properties and nitrogen uptake and growth of 'Elliot' highbush blueberry. Oregon State Univ., Corvallis, MS Thesis.

Yang, W.Q., B.L. Goulart, K. Demchak, and Y. Li. 2002. Interactive effects of mycorrhizal inoculation and organic amendment on nitrogen acquisition and growth of highbush blueberries. J. Amer. Soc. Hort. Sci. 127:742-748, https:// doi.org/10.21273/JASHS.127.5.742.

Zhang, Q., Z. Yang, and W. Wu. 2008. Role of crop residue management in sustainable agriculture development in the North China Plain. J. Sustain. Agr. 32:137-148, https://doi.org/ 10.1080/10440040802121502.

Zhang, Y., X. Wang, B. Liu, Q. Liu, H. Zheng, X. You, K. Sun, X. Luo, and F. Li. 2020. Comparative study of individual and co-application of biochar and wood vinegar on blueberry fruit yield and nutritional quality. Chemosphere 246: 125699, https://doi.org/10.1016/j.chemosphere. 2019.125699 . 